\title{
Pengaruh Pengetahuan Zakat, Motivasi Membayar Zakat dan Sosial Ekonomi Terhadap Kesediaan Dosen Universitas Tridinanti Palembang Dalam Membayar Zakat Profesi Melalui Pemotongan Gaji
}

\author{
Melia Frastuti ${ }^{1}$ dan Deta Trinanti Oktavia ${ }^{2}$ \\ 1-2 Jurusan Akuntansi, Universitas Tridinanti Palembang \\ Email: melia_frastuti@univ-tridinanti.ac.id \\ Email: detaodet@yahoo.com
}

\begin{abstract}
The problem of zakat in this country actually started from the low awareness of the muzakki (people who issue zakat) to do it and the low of public trust in the Amil Zakat Agency and the Zakat Institusion, even though any expertise and wok that is lawful, whether done alone or related to other parties, sucs as an employee, if thei income reach the nishab, then zakat must be issued. This study aims to see how the knowledge of zakat, motivation and social-economic on the willingness University of Tridinanti Palembang lecturers in paying professional zakat through salary deductions. The population in this study was 190 lecturers at the University of Tridinanti Palembang (UTP). The sampel technique used was purposive sample with the criteria of lecturers who had obtained lecturer certification, amounting to 121 people from 4 fakulties at UTP. The data analysis used is using multiple linear regressions analysis. The results of the study state that the knowledge of zakat, zakat motivation and social-economic have a positive.
\end{abstract}

Key word: Zakat Profession, Knowledge of Zakat, Motivation and Social-Economic

\begin{abstract}
Abstrak
Masalah zakat di negara ini sesungguhnya berpangkal pada rendahnya kesadaran para muzakki (orang yang mengeluarkan zakat) untuk berzakat dan lemahnya kepercayaan masyarakat terhadap Badan Amil Zakat dan Lembaga Zakat, padahal setiap keahlian dan pekerjaan apapun yang halal, baik yang dilakukan sendiri maupun yang terkait dengan pihak lain, seperti seorang pegawai atau karyawan, apabila penghasilan dan pendapatannya mencapai nishab, maka wajib dikeluarkan zakatnya. Penelitian ini bertujuan untuk melihat bagaimana pengetahuan zakat, motivasi dan sosial ekonomi terhadap kesediaan dosen Universitas Tridinanti Palembang (UTP) dalam membayar zakat profesi melalui pemotongan gaji. Populasi dalam penelitian ini berjumlah 190 dosen di Universitas Tridinati Palembang. Teknik sampel yang digunakan adalah purposive sample dengan kriteria dosen yang sudah memperoleh sertifikasi dosen yaitu berjumlah 121 orang dari 4 fakultas di UTP. Analisis data yang digunakan adalah menggunakan analisis regresi linear berganda. Hasil penelitian menyatakan bahwa pengetahuan zakat, motivasi zakat dan sosial ekonomi berpengaruh positif. Kata Kunci: Zakat Profesi, Pengetahuan Zakat, Motivasi dan Sosial Ekonomi
\end{abstract}

\section{Pendahuluan}

Begitu besarnya perkembangan zakat dalam 16 tahun terakhir dimana statistik zakat nasional mencatat bahwa pertumbuhan Zakat, Infak dan Sedekah (ZIS) dari tahun 2002- 2017 mengalami peningkatan yang cukup tinggi jika dibandingkan dengan pertumbuhan PDB di Indonesia berikut datanya tersaji dalam tabel 1: 
Tabel 1. Perbandingan Pertumbuhan Pengumpulan Zakat, Infak dan Sedekah (ZIS) dan Pertumbuhan PDB Tahun 2002-2017

\begin{tabular}{rrrrl}
\hline Tahun & $\begin{array}{c}\text { ZIS } \\
\text { (Milyar Rp) }\end{array}$ & $\begin{array}{c}\text { Pertumbuhan } \\
(\%)\end{array}$ & Pertumbuhan PDB (\%) & Keterangan \\
\hline 2002 & 68.39 & 0 & 3.7 & \\
2003 & 85.28 & 24.70 & 4.1 & Tsunami Aceh \\
2004 & 150.09 & 76.00 & 5.1 & \\
2005 & 295.52 & 96.90 & 5.7 & Gempa Yogya \\
2006 & 373.17 & 26.28 & 5.5 & \\
2007 & 740.00 & 98.30 & 6.3 & \\
2008 & 920.00 & 24.32 & 6.2 & \\
2009 & $1,200.00$ & 30.43 & 4.9 & \\
2010 & $1,500.00$ & 25.00 & 6.1 & \\
2011 & $1,729.00$ & 15.27 & 6.5 & \\
2012 & $2,212.00$ & 27.94 & 6.23 & \\
2013 & $2,639.00$ & 19.30 & 5.78 & \\
2014 & $3,300.00$ & 25.05 & 5.02 & \\
2015 & $3,650.00$ & 10.61 & 5.04 & \\
2016 & $5,017.29$ & 37.46 & 5.02 & \\
2017 & $6,224.37$ & 24.06 & 5.07 & \\
& Rerata & 35.10 & 5.39 & \\
\hline
\end{tabular}

Sumber: Statistik Zakat Nasional, tahun 2017

Dari tabel 1 tersaji bahwa rerata pertumbuhan Zakat, Infak dan Sedekah tahun 2002- 2017 sangat tinggi hingga mencapai 35,10 \% sedangkan pertumbuhan PDB Indonesia hanya mencapai 5,39 \%. Hal ini membuktian kesadaran masyarakat untuk menunaikan kewajiban zakat sudah sangat baik dan meningkat.

Yusuf al-Qaradhawi menyatakan bahwa di antara hal yang sangat penting untuk mendapatkan perhatian kaum muslimin saat ini adalah penghasilan atau pendapatan yang diusahakan melalui keahliannya, baik keahlian yang dilakukannya secara sendiri maupun secara bersama-sama. Yang dilakukan sendiri, misalnya profesi dokter, arsitek, ahli hukum, penjahit, pelukis, mungkin juga da'i atau muballigh, dan lain sebagainya. Yang dilakukan bersama-sama, misalnya pegawai (pemerintah maupun swasta) dengan menggunakan sistem upah atau gaji.

Wahbah az-Zuhaili secara khusus mengemukakan kegiatan penghasilan atau pendapatan yang diterima seseorang melalui usaha sendiri (wirausaha) seperti dokter, insinyur, ahli hukum, penjahit dan lain sebagainya. Dan juga yang terkait dengan pemerintah (pegawai negeri) atau pegawai swasta yang mendapatkan gaji atau upah dalam waktu yang relatif tetap, misalnya sebulan sekali. Penghasilan atau pendapatan yang semacam ini dalam istilah fiqh dikatakan sebagai al-maal almustafaad. Sementara itu, fatwa ulama yang dihasilkan pada waktu Muktamar Internasional Pertama tentang Zakat di Kuwait pada tanggal 29 Rajab $1404 \mathrm{H}$ yang bertepatan dengan tanggal 30 April 1984 M, bahwa salah satu kegiatan yang menghasilkan kekuatan bagi manusia sekarang adalah kegiatan profesi yang menghasilkan amal yang bermanfaat, baik yang dilakukan sendiri, seperti dokter, arsitek dan yang lainnya, maupun yang dilakukan secara bersama-sama, seperti para karyawan atau para pegawai. Semua itu menghasilkan pendapatan atau gaji. 
Berdasarkan uraian di atas, dapat disimpulkan bahwa setiap keahlian dan pekerjaan apapun yang halal, baik yang dilakukan sendiri maupun yang terkait dengan pihak lain, seperti seorang pegawai atau karyawan, apabila penghasilan dan pendapatannya mencapai nishab, maka wajib dikeluarkan zakatnya.

Masalah zakat di negara ini sesungguhnya berpangkal pada rendahnya kesadaran para muzakki (orang yang mengeluarkan zakat) untuk berzakat dan lemahnya kepercayaan masyarakat terhadap Badan Amil Zakat dan Lembaga Amil Zakat. Padahal Badan Amil Zakat dan Lembaga Amil Zakat adalah satu dari delapan golongan yang berhak menerima zakat. Selain itu, pengelolaan yang terhimpun oleh Badan Amil Zakat dan Lembaga Amil Zakat tertentu dapat membuat dana zakat menjadi produktif dan terencana sehingga dampak yang dihasilkan pun lebih bermanfaat (Absidah, 2010).

Sesuai dengan QS. At Taubah ayat 103 tergambar bahwa zakat yang dikeluarkan muzakki (orang yang mengeluarkan zakat) dapat membersihkan dan mensucikan hati mereka, tidak lagi mempunyai sifat yang tercela terhadap harta, seperti rakus dan kikir (Shobirin, 2015).

Zakat termasuk kekayaan rakyat yang diatur oleh pemerintah. Oleh karena itu keliru sekali apabila ada yang mengartikan bahwa zakat merupakan salah satu manifestasi kebaikan hati orang kaya terhadap orang miskin. Zakat itu sama sekali tidak didasarkan pada kehendak pribadi yang boleh dilaksanakan dan boleh tidak. Zakat wajib dilaksanakan rela atau tidak apabila telah mencapai nishab dan haul. Dari pengertian diatas dapat disimpulkan bahwa kekayaan seseorang yang beragama Islam wajib dizakatkan apabila telah mencapai nisabnya dan haul dari hasil berdagang, bertani, berternak,emas dan perak, hasil dari pekerjaan, profesi, investasi dan lain sebagainya (Dianingtyas, 2011).

Zakat merupakan suatu kewajiban muslim yang harus di tunaikan. Zakat memiliki aturan yang jelas, mengenai harta apa yang harus dizakatkan, batasan harta yang dizakatkan, demikian juga cara perhitungannya, bahkan siapa yang boleh menerimapun telah diatur oleh Allah SWT dan Rasul- Nya. Jadi zakat sesuatu yang sangat khusus, karena memiliki persyaratan dan aturan baku baik untuk alokasi, sumber, besaran maupun waktu tertentu yang telah ditetapkan oleh syariah (Wasilah dan Sri, 2015).

Di Indonesia sesuai dengan Undang-Undang No. 17 Tahun 2000 dan Keputusan Dirjen Pajak No. KEP-542/PJ/2001 bahwa zakat atas penghasilan dapat dikurangkan atas penghasilan neto, sehingga zakat atas penghasilan yang dibayarkan secara resmi oleh Wajib Pajak Orang Pribadi pemeluk Islam atau Wajib Pajak Badan Dalam Negeri yang dimiliki kaum muslim kepada Lembaga Amil Zakat resmi, dapat dikurangi atas penghasilan kena pajak. Namun yang berlaku untuk Undang-Undang ini hanya khusus tentang zakat atas penghasilan saja dan tidak berlaku untuk zakat harta yang lain. (Wasilah dan Sri, 2015)

\section{Landasan Teori dan Hukum Kewajiban Zakat Profesi dan Maqasid Al-Syariah dalam Pengelolaan Maqasid Al-Syariah dalam Pengelolaan Zakat}

Dari segi bahasa, zakat memiliki kata dasar "zaka" yang berarti berkah, tumbuh, suci, bersih dan baik. Sedangkan zakat secara terminologi berarti aktivitas memberikan harta tertentu yang diwajibkan Allah SWT dalam jumlah dan perhitungan tertentu untuk diserahkan kepada orang- orang yang berhak. (Heri, 2018:115). 
Semua penghasilan melalui kegiatan profesional tersebut, apabila telah mencapai nishab, maka wajib dikeluarkan zakatnya. Hal ini berdasarkan nash-nash yang bersifat umum, misalnya firman Allah SWT dalam QS At-Taubah: 103, QS AlBaqarah: 267 dan juga firman-Nya dalam QS Adz-Dzaariyaat: 19 yaitu:

"Ambillah zakat dari sebagian harta mereka, dengan zakat itu kamu membersihkan dan mensucikan mereka, dan mendo 'alah untuk mereka. Sesungguhnya do'a kamu itu (menjadi) ketenteraman jiwa bagi mereka. Dan Allah Maha Mendengar lagi Maha Mengetahui." (QS At-Taubah: 103).

"Hai orang-orang yang beriman, nafkahkanlah (di jalan Allah) sebagian dari hasil usahamu yang baik-baik dan sebagian dari apa yang Kami keluarkan dari bumi untuk kamu. Dan janganlah kamu memilih yang buruk-buruk lalu kamu nafkahkan darinya, padahal kamu sendiri tidak mau mengambilnya melainkan dengan memicingkan mata terhadapnya. Dan ketahuilah, bahwa Allah Maha Kaya lagi Maha Terpuji." (QS Al-Baqarah: 267).

"Dan pada harta-harta mereka ada hak untuk orang miskin yang meminta dan orang miskin yang tidak mendapat bagian" (QS Adz-Dzaariyaat: 19).

Menurut Asmawi (dalam Dakhoir, 2015:31) teori mashlahat ternyata melalui reformulasi oleh para ulama ahli Ushul sepanjang sejarah hukum Isla. Tentu saja dalam perjalanan sejarah tersebut terdapat dinamika pemikiran dalam formulasi teori mashlahat. Mashlahat dikemukakan oleh beberapa tokoh atau pakar hukum dengan rumusan subbstansi yang berbeda namun dalam tataran urgensi mashlaha mereka bersepakat sepenuhnya bahwa teori mashlahat merupakan teori multi-fungsi dalam berbagai masalah dalam dimensi hukum.

\section{Nishab, Waktu, Kadar dan Cara Zakat Profesi}

Menurut Ladewi ( 2014:195) orang yang berhak menerima zakat yaitu:

1. Orang fakir; orang yang amat sengsara hidupnya, tidak mempunyai harta dan tenaga untuk memenuhi penghidupannya.

2. Orang miskin; orang yang tidak cukup penghidupannya dan dalam keadaan kekurangan.

3. Pengurus zakat; orang yang diberi tugas untuk mengumpulkan dan membagikan zakat.

4. Muallaf; orang kafir yang ada harapan masuk Islam dan orang yang baru masuk Islam yang imannya masih lemah.

5. Memerdekakan budak; mencakup juga untuk melepaskan Muslim yang ditawan oleh orang kafir.

6. Orang berhutang, orang yang berhutang karena untuk kepentingan yang bukan maksiat dan tidak sanggup membayarnya. Adapun orang yang berhutang untuk memelihara persatuan umat Islam dibaya hutangnya itu dengan zakat, walaupun ia mampu membayarnya.

7. Pada jalan Allah (sabillah) yaitu untuk keperluan pertahanan Islam dan kaum muslimin, di antara mufasirin ada yang berpendapat bahwa fisabillah itu mencakup juga kepentingan- kepentingan umum seperti mendirikan sekolah, rumah sakit dan lain-lain.

8. Orang yang sedang dalam perjalanan yang bukan maksiat mengalami kesengsaraan dalam perjalanannya.

Menurut Hari (2018: 120-121) syarat harta kekayaan yang wajib dizakatkan oleh objek zakat adalah: 
1. Halal, harta tersebut harus didapatkan dengan cara yang ba'i yang halal (sesuai dengan tuntutan syariah).

2. Milik penuh, artinya kepemilikkan di sini berupa hak untuk penyimpanan, pemakaian dan pengelolaan yang diberikan Allah SWT kepada manusia, dan didalamnya tidak ada hak orang lain.

3. Berkembang, menurut ahli fikih "harta yang berkembang" secara terminologi berarti harta tersebut bertambah".

4. Cukup nisab, Nisab yaitu jumlah minimal yang menyebabkan harta terkena kewajiban zakat.

5. Cukup Haul, Haul adalah jangka waktu kepmilikkan harta di tangan si pemilik yaitu sudah melampaui 12 bulan Qamariyah.

6. Bebas dari hutang, dalam riwayat HR Bukhari menyebutkan bahwa "zakat hanya dibebankan ke atas pundak orang kaya. orang yang berzakat sedangkan ia atau keluarganya membutuhkan, atau ia mempunyai hutang, maka utang itu lebih penting dibayar terlebih dahulu dari pada zakat"

7. Lebih dari kebutuhan pokok. Kebutuhan adalah sesuatu yang benar- benar diperlukan untuk kelangsungan hidup secara rutin.

Terdapat beberapa kemungkinan kesimpulan dalam menentukan nishab, kadar dan waktu mengeluarkan zakat profesi. Hal ini sangat bergantung pada qiyas (analogi) yang dilakukannya. (baznas.go.id)

Pertama, jika dianalogikan pada zakat perdagangan, maka nishab, kadar, dan waktu mengeluarkannya sama dengannya dan sama pula dengan zakat emas dan perak. Nishabnya senilai 85 gram emas, kadar zakatnya 2,5 \% (persen) dan waktu mengeluarkannya setahun sekali.

Contoh: Jika si A berpenghasilan Rp 10.000.000 setiap bulan maka besar zakat yang dikeluarkannya adalah: 2,5 \% x 12 x Rp 10.000 .000 sebesar Rp 3.000.000 per tahun atau Rp 250.000 per bulan.

Kedua, jika dianalogikan pada zakat pertanian, maka nishabnya senilai $653 \mathrm{~kg}$ padi atau gandum, kadar zakatnya sebesar lima persen dan dikeluarkan pada setiap mendapatkan gaji atau penghasilan, misalnya sebulan sekali. Dalam contoh kasus di atas, maka kewajiban zakat si A adalah sebesar 5\% x Rp 10.000.000 atau sebesar Rp 500.000 per bulan.

Ketiga, jika dianalogikan pada zakat rikaz, maka zakatnya sebesar 20 persen tanpa ada nishab, dan dikeluarkan pada saat menerimanya (Pada contoh di atas, maka si A mempunyai kewajiban berzakat sebesar $20 \%$ x Rp 10.000 .000 atau sebesar Rp 2.000.000 setiap bulan.)

Zakat profesi bisa dianalogikan pada dua hal secara sekaligus, yaitu pada zakat pertanian dan pada zakat emas dan perak. Dari sudut nishab dianalogikan pada zakat pertanian, yaitu sebesar lima ausaq atau senilai $653 \mathrm{~kg}$ padi/ gandum dan dikeluarkan pada saat menerimanya. Misalnya setiap bulan bagi karyawan yang menerima gaji bulanan langsung dikeluarkan zakatnya, sama seperti zakat pertanian yang dikeluarkan pada saat panen, sebagaimana digambarkan Allah SWT dalam QS Al-An'aam: 141.

Karena dianalogikan pada pada zakat pertanian, maka bagi zakat profesi tidak ada ketentuan haul. Ketentuan waktu menyalurkannya adalah pada saat menerima, misalnya setiap bulan, dapat didasarkan pada 'urf (tradisi) di sebuah negara. Karena itu profesi yang menghasilkan pendapatan setiap hari, misalnya dokter yang 
membuka praktek sendiri, atau para da'i yang setiap hari berceramah, zakatnya dapat dikeluarkan setiap hari atau sebulan sekali.

\section{Perhitungan Zakat Profesi}

Adapun contoh penghitungan zakat profesi adalah sebagai berikut; Pak Ahmad, dalam satu haul (siklus satu tahun hijriyah) didapati data:

\begin{tabular}{|c|c|c|}
\hline $\mathrm{a}$ & Penghasilan dalam 1 haul & Rp 5.000/bln x 12 \\
\hline b & Kebutuhan pokok keluarga & Rp $2.000 /$ bln $\times 12$ \\
\hline C & Biaya sekolah anak & $\mathrm{Rp} 800.000 / \mathrm{bln} \times 12=\mathrm{Rp} 9.600 .000$ \\
\hline $\mathrm{d}$ & Biaya listrik dan air & Rp 300.000/bln x $12=\mathrm{Rp} 3.600 .000$ \\
\hline \multicolumn{2}{|r|}{ Penghasilan Bersih } & $=\mathrm{Rp} 22.800 .000$ \\
\hline
\end{tabular}

Berdasarkan data di atas, maka penghasilan bersih pak Ahmad dalam satu haul telah mencapai nishab dengan standar nishab dirham. Maka ia dikenakan zakat sebesar Rp. $22.800 .000 \times 2,5 \%=\mathrm{Rp} 570.000$, maka pembayaran dengan cara taqsit adalah sebesar Rp 570.000 : 12 (bulan hijriyah) = Rp. 47.500/bulan (Sulaiman, 2016).

\section{Fungsi Badan Amil Zakat Nasional di Indonesia}

Dalam lima tahun terakhir ini secara statistik pengumpulan zakat yang dilakukan oleh BAZNAS dan LAZ terlihat kian bertambah dengan rata-rata pertumbuhan sebesar 23,3\%, mulai dari zakat Maal, Infak/ Sedekah/ Zakat Fitrah dan dana sosial keagamaan lainnya. Berikut tabel 2 perbandingan penghimpunan berdasarkan jenis dana 2016- 2017 yaitu:

Tabel 2. Perbandingan Penghimpunan Berdasarkan Jenis Dana Tahun 2016- 2017

\begin{tabular}{|c|c|c|c|c|}
\hline Jenis Dana & Realisasi 2016 & $\%$ & Realisasi 2017 & $\%$ \\
\hline Zakat Maal-Penghasilan Individu & $2,843,695,144,686$ & 56.68 & $2,785,208,957,779$ & 44.75 \\
\hline Zakat Maal-Badan & $620,546,547,627$ & 12.37 & $307,007,314,242$ & 4.93 \\
\hline Zakat Maal-Lainnya & 0 & 0.00 & 0 & 0.00 \\
\hline Infak/Sedekah Perorangan & $858,631,089,706$ & 17.11 & $1,651,254,048,632$ & 26.53 \\
\hline Infak/Sedekah/CSR/PKBL Badan & $142,867,215,300$ & 2.85 & $113,629,148,360$ & 1.83 \\
\hline Zakat Fitrah Ramadhan & $273,975,100,183$ & 5.46 & $1,101,926,162,357$ & 17.70 \\
\hline Dana Sosial Keagamaan Lainnya & $277,336,514,452$ & 5.53 & $265,345,638,101$ & 4.26 \\
\hline Dana Lain-lain & $241,514,997$ & 0.00 & 0 & 0.00 \\
\hline Jumlah & $5,017,293,126,950$ & 100.00 & $6,224,371,269,471$ & 100.00 \\
\hline
\end{tabular}

Sumber: Statistik Zakat Nasional Tahun 2017

Dari tabel di atas dapat dilihat peningkatan jumlah zakat tahun 2016 dari 5,0 Triliun naik menjadi 6,2 triliun di tahun 2017. Hal ini menunjukkan bahwa kesadaran masyarakat semakin baik dalam menunaikan zakat melalui amil zakat resmi. Kemudian apabila dilihat dengan rerata pertumbuhan PDB dalam lima tahun terakhir yang sebesar 5,2\% menunjukkan bahwa potensi zakat memang seyogianya dapat digunakan untuk mengurangi kemiskinan dan memoderasikan kesenjangan pendapatan antara si miskin dengan si kaya. Melihat kondisi ini tentunya BAZNAS terus berupaya membantu pemerintah dalam mengentaskan kemiskinan dengan berbagaimacam program dari lima bidang penyaluran yang sudah berjalan bertahuntahun lamanya. Fungsi koordinator yang dimandatkan oleh Undang-Undang 23/2011 kepada BAZNAS menjadi modal utama dalam memantau dan membuat regulasi untuk menjadi acuan terhadap aktivitas penyaluran BAZNAS provinsi/ kabupaten/ kota dan LAZ untuk menjaga rasio penyaluran terhadap pengumpulan berada pada posisi 
Efektif pada penilaian yang dikeluarkan oleh Zakat Core Principle (ZCP) dengan nilai di tahun 2017 ini adalah 78.08\%. Sementara itu realitas pengelolaan zakat secara nasional di tahun 2017 berada pada angka 2,9\% dari potensi 217 trilliun rupiah. Zakat masih mendominasi pengumpulan secara nasional dengan kisaran 67,4\%, dan sisanya yang 32,6\% adalah infak, sedekah dan dana sosial keagamaan lainya. (Statistik Zakat Nasional, Tahun 2017)

\section{Tunjangan dan Layanan Pegawai}

Tunjangan dan layanan pegawai (employee benefit and services) biasanya dijelaskan sebagai pembayaran in-kind (bukan berupa uang) kepada pegawai atas keanggotaan atau partisipasinya dalam perusahaan. Tunjangan dan layanan memungkinkan pegawai untuk menikmati kehidupan yang lebih baik dan mempertahankan keseimbangan hidup/pekerjaannya. (Jackson, 2011:216)

Menurut Noe (2011:106) ada program-program menghargai kontribusi karyawan, dapat di lihat dari Tabel 3 sebagai berikut:

Tabel 3. Program-Program Menghargai Kontribusi Karyawan

\begin{tabular}{|c|c|c|c|c|c|c|}
\hline & Gaji Merit & Gaji Insentif & Bagi Hasil & Kepemilikan & Bagi Untung & Berbasis Skil \\
\hline $\begin{array}{l}\text { Fitur Desain } \\
\text { Metode } \\
\text { Pembayaran }\end{array}$ & $\begin{array}{l}\text { Perubahan Gaji } \\
\text { Pokok }\end{array}$ & Bonus & Bonus & $\begin{array}{l}\text { Perubahan } \\
\text { Ekuitas }\end{array}$ & Bonus & $\begin{array}{l}\text { Perubahan gaji } \\
\text { pokok }\end{array}$ \\
\hline $\begin{array}{l}\text { Frekuensi } \\
\text { Pembayaran }\end{array}$ & Tahunan & Mingguan & $\begin{array}{c}\text { Semesteran/ } \\
\text { tahunan }\end{array}$ & $\begin{array}{l}\text { Ketika saham } \\
\text { terjual }\end{array}$ & Bulanan/ triwulan & $\begin{array}{l}\text { Saat skill/kompetensi } \\
\text { didapatkan }\end{array}$ \\
\hline $\begin{array}{l}\text { Ukuran } \\
\text { Kinerja }\end{array}$ & $\begin{array}{l}\text { Penilaian } \\
\text { supervisior } \\
\text { terhadap kinerja } \\
\text { individu }\end{array}$ & $\begin{array}{c}\text { Output } \\
\text { individual, } \\
\text { produktivitas, } \\
\text { penjualan }\end{array}$ & Profit perusahan & $\begin{array}{l}\text { Return saham } \\
\text { perusahaan }\end{array}$ & $\begin{array}{c}\text { Produksi/ biaya } \\
\text { terkendalikan dari } \\
\text { unit kerja } \\
\text { tersendiri }\end{array}$ & $\begin{array}{c}\text { Akuisisi skil/ } \\
\text { kompetensi individu }\end{array}$ \\
\hline Konsekuensi & & & & & & \\
\hline $\begin{array}{l}\text { Motivasi } \\
\text { Kinerja }\end{array}$ & $\begin{array}{c}\text { Hubungan antara } \\
\text { gaji dengan kinerja } \\
\text { beragam }\end{array}$ & $\begin{array}{c}\text { Kaitan jelas } \\
\text { antara kinerja } \\
\text { dengan reward }\end{array}$ & $\begin{array}{l}\text { Lebih kuat di } \\
\text { perusahaan kecil }\end{array}$ & $\begin{array}{l}\text { Lebih kuat di } \\
\text { perusahaan } \\
\text { kecil }\end{array}$ & $\begin{array}{l}\text { Lebih kuat di unit } \\
\text { kecil }\end{array}$ & $\begin{array}{l}\text { Mendorong } \\
\text { pembelajaran }\end{array}$ \\
\hline Atraksi & $\begin{array}{l}\text { Seiring waktu } \\
\text { Kinerja kian baik } \\
\text { akan juga dibayar } \\
\text { semakin baik }\end{array}$ & $\begin{array}{c}\text { Yang } \\
\text { berprestasi } \\
\text { dibayar lebih }\end{array}$ & $\begin{array}{l}\text { Membantu semua } \\
\text { karyawan ketika } \\
\text { rancangan } \\
\text { menyalurkan } \\
\text { pembayaran } \\
\text { dividen }\end{array}$ & $\begin{array}{l}\text { Dapat } \\
\text { membantu } \\
\text { penguncian } \\
\text { karyawan }\end{array}$ & $\begin{array}{c}\text { Membantu } \\
\text { semua karyawan } \\
\text { ketika rancangan } \\
\text { menyalurkan } \\
\text { pembayaran } \\
\text { dividen }\end{array}$ & $\begin{array}{l}\text { Menarik karyawan } \\
\text { berorientasi } \\
\text { pembelajaran }\end{array}$ \\
\hline Budaya & $\begin{array}{l}\text { Kompetensi } \\
\text { individual }\end{array}$ & $\begin{array}{l}\text { Kompetensi } \\
\text { individual }\end{array}$ & $\begin{array}{l}\text { Wawasan bisnis } \\
\text { \& kerjasama }\end{array}$ & $\begin{array}{l}\text { Rasa memiliki } \\
\text { \& kerjasama }\end{array}$ & $\begin{array}{l}\text { Mendukung } \\
\text { kerjasama, } \\
\text { pemecahan } \\
\text { masalah }\end{array}$ & $\begin{array}{l}\text { Organisasi yang } \\
\text { fleksibel \& } \\
\text { pembelajar }\end{array}$ \\
\hline Biaya & $\begin{array}{l}\text { Memerlukan sistim } \\
\text { penilaian kinerja } \\
\text { yang mapan }\end{array}$ & $\begin{array}{l}\text { Menentukan \& } \\
\text { menjaga } \\
\text { standar } \\
\text { toleransi }\end{array}$ & $\begin{array}{c}\text { Mengaitkan biaya } \\
\text { dengan } \\
\text { kemampuan } \\
\text { membayar }\end{array}$ & $\begin{array}{c}\text { Mengaitkan } \\
\text { biaya dengan } \\
\text { kemampuan } \\
\text { membayar }\end{array}$ & $\begin{array}{c}\text { Menetapkan \& } \\
\text { menjaga standar } \\
\text { toleransi }\end{array}$ & $\begin{array}{l}\text { Pelatihan \& } \\
\text { Sertifikasi }\end{array}$ \\
\hline $\begin{array}{l}\text { Kontigensi } \\
\text { Gaya } \\
\text { Manajemen }\end{array}$ & $\begin{array}{l}\text { Sebagai partisipasi } \\
\text { diinginkan }\end{array}$ & Kontrol & Partisipasi baik & $\begin{array}{l}\text { Partisipasi } \\
\text { baik }\end{array}$ & Partisipasi baik & Partisipasi baik \\
\hline Tipe & & & & & & Kedalaman skill yang \\
\hline
\end{tabular}




\begin{tabular}{|l|c|c|c|c|c|c|}
\hline Pekerjaan & $\begin{array}{c}\text { penilaian grup } \\
\text { dilakukan }\end{array}$ & $\begin{array}{c}\text { individual, } \\
\text { mudah diukur }\end{array}$ & Semua tipe & Semua tipe & Semua tipe & signifikan \\
\hline
\end{tabular}

Sumber : (Noe, 2011:106)

\section{Tunjangan Sertifikasi Dosen}

Dosen wajib memiliki kualifikasi akademik, kompetensi, sertifikat pendidik, sehat jasmani dan rohani, dan memenuhi kualifikasi lain yang dipersyaratkan satuan pendidikan tinggi tempat bertugas, serta memiliki kemampuan untuk mewujudkan tujuan pendidikan nasional. (Bab II Pasal 2 Peraturan Pemeritah RI Nomor 37 Tahun 2009)

Dalam PP RI Nomor 41 Tahun 2009 Bab II Pasal 3 disebutkan bahwa:

1. Guru dan dosen yang telah memiliki sertifikat pendidik dan memenuhi persyaratan sesuai dengan ketentuan peraturan perundang-undangan diberi tunjangan profesi setiap bulan.

2. Tunjangan profesi sebagaimana dimaksud pada ayat (1) diberikan kepada guru dan dosen pegawai negeri sipil dan bukan pegawai negeri sipil.

Pada Pasal 4 nya disebutkan juga bahwa Tunjangan Profesi bagi guru dan dosen pegawai negeri Sipil yang menduduki jabatan fungsional guru dan dosen diberikan sebesar 1 (satu) kali gaji pokok pegawai negeri sipil yang bersangkutan sesuai dengan ketentuan peraturan perundang-undangan.

Dilanjutkan Pasal 5 Tunjangan profesi bagi guru dan dosen bukan pegawai negeri sipil diberikan sesuai dengan kesetaraan tingkat, masa kerja, dan kualifikasi akademik yang berlaku bagi guru dan dosen pegawai negeri sipil. (PP RI Nomor 41 Tahun 2009).

\section{Dimensi Pekerjaan}

Menurut Koesomowidjojo (2017: 8-12) dimensi-dimensi pekerjaan mempengaruhi dan menentukan tingkat produktifitas karyawan dan kepuasan yang diperoleh atas pekerjaan yang dilakukan terhadap suatu produk/ jasa. Dimensi tersebut adalah:

1. Dimensi fisik, yang menjadi perhatian meliputi kecepatan, gerak, dan bagaimana langkah pekerja dalam menyelesaikan pekerjaan.

2. Dimensi kultural, memberikan pandangan bahwa dengan sebuah pekerjaan seseorang akan mendapatkan gaji, kedudukan dan status sosial yang berpengaruh pada bagaimana kedudukan sosial dan kualitas kehidupan seorang karyawan. Semakin baik tingkat pekerjaan gaji yang didapat secara signifikan akan meningkat.

3. Dimensi psikologis, pekerjaan berpengaruh pada pemenuhan kebutuhan psikologis berupa pertumbuhan, pengetahuan dan pengembangan.

4. Dimensi sosial, dengan memiliki pekerjaan dan terciptanya lapangan pekerjaan, akan memberikan kontribusi terhadap kesejahteraan social bagi keluarga masyarakat, lingkungan dan negara.

5. Dimensi kekuasaan, atasan memiliki kekuasaan untuk memberikan penilaian atas kinerja karyawan sebagai usaha meningkatkan produktifitas.

Adapun permasalahan dalam penelitian Absidah (2011) adalah tingkat kesadaran kayawan dan faktor-faktor yang mempengauhi kesadaan karyawan BRI Syariah Cabang Yogyakarta dalam membayar zakat profesi. Penelitian ini merupakan 
penelitian langsung (field research). Metodologi penelitian ini menggunakan pendekatan kuantitatif dengan data diambil menggunakan kuesioner dengan teknik penarikan sampel secaa acak kepada para amil. Berdasarkan hasil analisis dan pembahasan yang dilakukan variabel yang bepengaruh terhadap kesadaran membayar zakat hanya tiga variabel yaitu variabel sosial ekonomi, profesionalitas dan manajemen, sedangkan variabel pengetahuan agama dan motivasi tidak berpengaruh terhadap kesadaran karyawan dalam membayar zakat pofesi. Penelitian ini dijadikan salah satu penelitian terdahulu.

\section{Kerangka Penelitian}

Gambar 1 yang menyajikan Kerangka Pemikiran penelitian ini sebagai berikut:

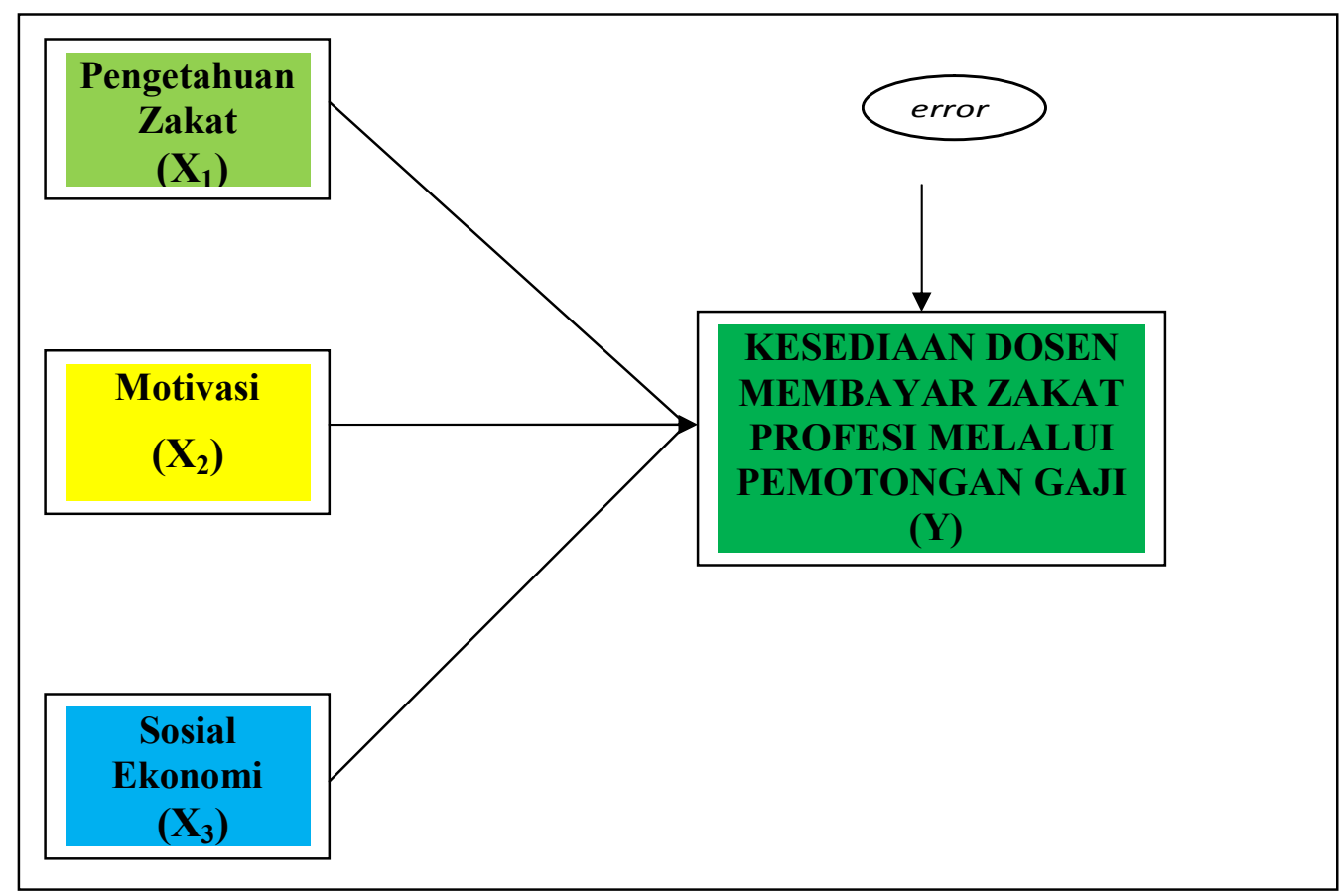

Gambar 1. Kerangka Pemikiran

\section{Hipotesis Penelitian} berikut:

Hipotesis yang ingin diharapkan dalam penelitian ini dapat dijabarkan sebagai

$\mathbf{H}_{1}$ : Adanya pengaruh positif pengetahuan zakat_terhadap kesediaan Dosen Universitas Tridinanti dalam membayar zakat profesi melalui pemotongan gaji.

$\mathbf{H}_{2}$ : Adanya pengaruh positif motivasi terhadap kesediaan Dosen Universitas Tridinanti dalam membayar zakat profesi melalui pemotongan gaji.

$\mathbf{H}_{3}$ : Adanya pengaruh positif sosial ekonomi terhadap kesediaan Dosen Universitas Tridinanti dalam membayar zakat profesi melalui pemotongan gaji.

$\mathbf{H}_{4}$ : Adanya pengaruh positif pengetahuan agama, motivasi dan sosial ekonomi terhadap kesediaan Dosen Universitas Tridinanti dalam membayar zakat profesi melalui pemotongan gaji. 


\section{Metode Penelitian}

Penelitian ini dilakukan di Universitas Tridinanti, Jalan Kapten Marzuki Nomor 2446, 20 Ilir D III, Ilir Timur I, Kota Palembang Provinsi Sumatera Selatan Kode Pos 30129, Telepon (0711) 354654, Fax (0711) 358566. Teknik pengumpulan data primer dilakukan dengan metode survey lapangan dengan membagikan kuesioner kepada dosen yang telah mendapatkan tunjangan sertifikasi dosen di Universitas Tridinanti Palembang.

Populasi penelitian ini adalah dosen Universitas Tridinanti berikut daftar jumlah dosen masing- masing Fakultas, yaitu:

Tabel 4. Jumlah Populasi dalam Kriteria Sudah Bersertifikasi dan Belum Bersertifikasi Pendidik

\begin{tabular}{llccc}
\hline No & \multicolumn{1}{c}{ Fakultas } & $\begin{array}{c}\text { Sudah } \\
\text { Bersertifikasi }\end{array}$ & $\begin{array}{c}\text { Belum } \\
\text { Bersertifikasi }\end{array}$ & $\begin{array}{c}\text { Jumlah } \\
\text { (orang) }\end{array}$ \\
\hline 1 & Ekonomi & $\mathbf{5 5}$ & 30 & 85 \\
$\mathbf{2}$ & Teknik & 35 & 31 & 66 \\
3 & Pertanian & 19 & 2 & 21 \\
4 & Keguruan dan IImu & & & 18 \\
& Pendidikan & 12 & 6 & 190 \\
\hline & Total & 121 & 69 & \\
\hline
\end{tabular}

Sumber: Lembaga Penjamin Mutu (LPM) Universitas Tridinanti Tahun 2018

Dalam penelitian ini teknik sampling yang digunakan yaitu non probability sampling dengan teknik purposive sampling. Menurut Sugiyono (2016:85) bahwa: "purposive sampling adalah teknik pengambilan sampel sumber data dengan pertimbangan tertentu."

Alasan menggunakan teknik Purposive Sampling adalah karena tidak semua sampel memiliki kriteria yang sesuai dengan fenomena yang diteliti. Oleh karena itu, penulis memilih teknik Purposive Sampling yang menetapkan pertimbanganpertimbangan atau kriteria- kriteria tertentu yang harus dipenuhi oleh sampelsampel yang digunakan dalam penelitian ini.

Dalam penelitian ini yang menjadi sampel yaitu dosen yang memenuhi kriteria tertentu. Adapun kriteria yang dijadikan sebagai sampel penelitian yaitu:

1. Dosen yang telah memiliki sertifikasi pendidik.

2. Dosen tersebut memiliki penghasilan lebih besar sehingga tergolong memiliki kriteria mampu melakukan pembayaran zakat profesi setiap bulannya melalui pemotongan gaji.

Total sampel yang digunakan ada 121 (seratus dua puluh satu) orang dosen dari empat fakultas yang ada di Universitas Tridinanti.

Instrumen penelitian yang digunakan dalam penelitian ini adalah kuesioner, yang berisi mengenai pertanyaan dan pernyataan yang akan dijawab responden. Skala yang digunakan adalah Skala Likert (Likert Scale) didesain untuk menelaah seberapa kuat subjek setuju atau tidak setuju dengan pernyataan pada skala 4 titik dengan susunan.

\begin{tabular}{ccccc}
\hline Sangat Tidak & Tidak & Netral & Setuju & Sangat \\
Setuju & Setuju & & & Setuju \\
$\mathbf{1}$ & $\mathbf{2}$ & $\mathbf{3}$ & $\mathbf{4}$ & $\mathbf{5}$ \\
\hline
\end{tabular}


Respons terhadap sejumlah item yang berkaitan dengan konsep atau variabel tertentu kemudian disajikan kepada tiap responden. Ini adalah skala interval (interval scale) dan perbedaan dalam respons antara dua titik pada skala tetap sama. (Sekaran, 2011:31)

Uji regresi digunakan untuk meramalkan suatu variabel (variabel dependent) bedasarkan satu variabel atau beberapa variabel lain (variabel independent) dalam suatu persamaan linear, yaitu: $Y=a+b_{1} X_{1}+b_{2} X_{2} \ldots+b_{n} X_{n}$ persamaan linear dengan beberapa variabel independent. (Trihendradi $C$, 2013:155). Teknik analisis datanya menggunakan model regresi linear berganda (multiple linear regression). Model yang digunakan adalah sebagai berikut:

$$
Y_{1 t}=a+b_{1} X_{1}+b_{2} X_{2}+b_{3} X_{3}+e_{1 t}
$$

Keterangan :

$Y_{1 t} \quad=$ Kesediaan Dosen Membayar Zakat Profesi melalui pemotongan gaji

$X_{1} \quad=$ Pengetahuan Zakat;

$X_{2} \quad=$ Motivasi;

$X_{3} \quad=$ Sosial Ekonomi;

$a, b_{1}, b_{2}, b_{3} \quad=$ Konstanta

$e_{1 t} \quad=$ error

\section{Hasil dan Pembahasan}

Deskripsi Statistik Kualitatif

Analisis deskriptif pada responden berdasarkan jenis kelamin, diketahui bahwa terdapat ketidakseimbangan jumlah responden pria dan wanita, berikut perinciannya pada tabel 5:

Tabel 5. Jenis Kelamin Responden

\begin{tabular}{clccc}
\hline No & Fakultas & Pria (orang) & Wanita (orang) & Jumlah (orang) \\
\hline 1 & Ekonomi & 26 & 26 & 52 \\
2 & Teknik & 24 & 11 & 35 \\
3 & Pertanian & 9 & 10 & 19 \\
4 & Keguruan IImu & & & 12 \\
& Pendidikan & 4 & 8 & 121 \\
\hline
\end{tabular}

Sumber: Data olahan primer, Tahun 2018

Dari 121 (seratus dua puluh satu) responden yang berpartisipasi dalam penelitian ini, responden yang berjenis kelamin pria sebanyak 65 orang atau sebesar $54,1 \%$. Responden yang berjenis kelamin wanita sebanyak 56 orang atau sebesar $46,2 \%$. Hal ini dapat dilihat bahwa responden di dominasi oleh pria.

Analisis selanjutnya adalah analisis deskripsi Pangkat/ Golongan responden yang dapat dilihat pada tabel 6 di bawah ini:

Tabel 6. Pangkat/ Golongan Responden

\begin{tabular}{ccc}
\hline No & Pangkat/ Golongan & Jumlah (orang) \\
\hline 1 & IV/d & 10 \\
2 & IV/c & 8 \\
3 & IV/b & 2 \\
4 & IV/a & 17 \\
\hline
\end{tabular}




\begin{tabular}{lrc}
\hline 5 & $I I I / d$ & 14 \\
6 & $I I I / c$ & 42 \\
7 & $I I I / b$ & 28 \\
8 & $I I I / a$ & - \\
& Total & 121 \\
\hline
\end{tabular}

Sumber: LPM Universitas Tridinanti, tahun 2018

Dari tabel 6 di atas yang mendominasi pada dosen yang memiliki Pangkat/ Golongan III/c yaitu sebanyak 42 orang diikuti III/b sebanyak 28 orang, IV/a sebanyak 17 orang. Kemudian Pangkat/ Golongan III/d sebanyak 14 orang, IV/d sebanyak 10 orang, IV/c sebanyak 8 orang serta IV/b sebanyak 2 orang, sedangkan III/a tidak ada.

Deskriptif penggunaan sisa pendapatan responden digunakan dengan kategori: Belanja bersama keluarga, Liburan bersama keluarga, Simpan di bank, Liburan bersama teman kantor, dan lainnya dapat dilihat pada tabel 7 berikut ini:

Tabel 7. Penggunaan Sisa Pendapatan Responden

\begin{tabular}{clcc}
\hline No & \multicolumn{1}{c}{ Kategori } & Jumlah (orang) & Persentase (\%) \\
\hline 1 & Belanja bersama keluarga & 22 & 18,2 \\
2 & Liburan bersama keluarga & 19 & 15,7 \\
3 & Simpan di bank & 72 & $\mathbf{5 9 , 5}$ \\
4 & Liburan bersama teman kantor & 5 & 4,1 \\
5 & Lainnya $\quad$ Total & 3 & 2,5 \\
& & 121 & 100 \\
\hline
\end{tabular}

Sumber: Data olahan primer, tahun 2018

Dari tabel 7 dapat dilihat bahwa responden lebih sering menggunakan sisa pendapatannya untuk di simpan di bank, yaitu sebesar 59,5 \%. Sedangkan selebihnya responden lebih memilih untuk belanja bersama keluarga sebanyak 18,2 \%, liburan bersama keluarga sebanyak $15,7 \%$, liburan bersama teman kantor 4,1 \% atau penggunaan keperluan lainnya sebanyak 2,5\%.

Deskripsi pengetahuan zakat responden tentang landasan hukum zakat profesi selain Al-Quran Surah Al-Baqarah ayat 267 juga Undang- Undang Nomor 38 tahun 1999 ayat 11 ayat 2 Bab 4 tentang obyek zakat yang memasukkan obyek zakat yang baru seperti perusahaan, pendapatan, jasa (profesi), dilihat dari tabel 8, berikut:

Tabel 8. Pengetahuan Zakat Profesi Responden

\begin{tabular}{cccc}
\hline No & Pengetahuan Zakat Profesi & Responden (orang) & Persentase (\%) \\
\hline 1 & Sudah mengerti & 68 & 56,2 \\
2 & Belum mengerti & 53 & 43,8 \\
& Total & 121 & 100 \\
\hline
\end{tabular}

Sumber: Data olahan primer, tahun 2018

Dari data di atas dapat disimpulkan bahwa $55 \%$ responden sudah mengerti tentang pengetahuan zakat dari Al-Quran Surah Al-Baqarah ayat 267 juga UndangUndang Nomor 38 tahun 1999 ayat 11 ayat 2 Bab 4 tentang obyek zakat yang memasukkan obyek zakat yang baru seperti perusahaan, pendapatan, jasa (profesi). Sisanya $44,9 \%$ belum memahami.

Deskipsi Responden yang membayar/ mengeluarkan Zakat Profesi dapat dilihat pada tabel 9 berikut ini:

Tabel 9. Responden yang Membayar/ Mengeluarkan Zakat Profesi 


\begin{tabular}{cccc}
\hline No & $\begin{array}{c}\text { Membayar / } \\
\text { Mengeluarkan Zakat } \\
\text { Profesi }\end{array}$ & Responden (orang) & Persentase (\%) \\
\hline 1 & Sudah & 70 & 57,8 \\
2 & Belum & 51 & 42,2 \\
& Total & 121 & 100 \\
\hline
\end{tabular}

Sumber: Data olahan primer, tahun 2018

Dari tabel di atas dapat di lihat bahwa responden sebanyak 70 orang telah mengeluarkan zakat profesinya yaitu sebesar 57,8 \%. Sedangkan 51 orang belum mengeluarkan zakat profesinya yaitu sebesar $42,2 \%$.

Deskripsi cara responden membayar/ menyalurkan zakat profesi dengan kategori: Memberikan langsung kepada mustahik yang berhak menerima zakat, Melalui lembaga amil zakat daerah (LAZDA/BAZDA), Melalui pengurus masjid setempat, Melalui amil zakat di kantor/ perusahaan, dapat dilihat pada tabel 10 yaitu:

Tabel 10. Cara Responden Membayar/ Menyalurkan Zakat Profesi

\begin{tabular}{clcc}
\hline No & \multicolumn{1}{c}{ Kategori } & Responden (orang) & Persentase (\%) \\
\hline 1 & $\begin{array}{l}\text { Memberikan langsung kepada mustahik } \\
\text { yang berhak menerima zakat }\end{array}$ & 71 & 58,6 \\
2 & $\begin{array}{l}\text { Melalui lembaga amil zakat daerah } \\
(\text { LAZDA/BAZDA) }\end{array}$ & 3 & 2,4 \\
Melalui pengurus masjid setempat & 47 & 38,8 \\
4 & Melalui amil zakat di kantor/ perusahaan & - & - \\
& Total & 121 & 100 \\
\hline
\end{tabular}

Sumber: data olahan primer, tahun 2018

Dari tabel 10 di atas responden lebih banyak memberikan langsung kepada mustahik yang berhak menerima zakat sebesar 58,6 \%, kemudian dengan cara melalui pengurus masjid etempat sebanyak 38,8 \% sedangkan memalui lembaga amil zakat daerah (Lazda/Bazda) sebanyak 2,4\%.

\section{Deskripsi Statistik Kuantitatif}

Persamaan regresi digunakan untuk meramalkan suatu variabel (variabel dependen) berdasarkan satu atau beberapa variabel lain (variabel independen) dalam suatu persamaan linear (Trihendradi C, 2013: 155). Nilai b dan a untuk persamaan regresi pada dari kesedian dosen UTP dalam membayar zakat profesi melalui pemotongan gaji (Y) dapat dilihat pada tabel 11 berikut ini:

Tabel 11. Hasil Uji Regresi Linear Berganda

Coefficients $^{a}$

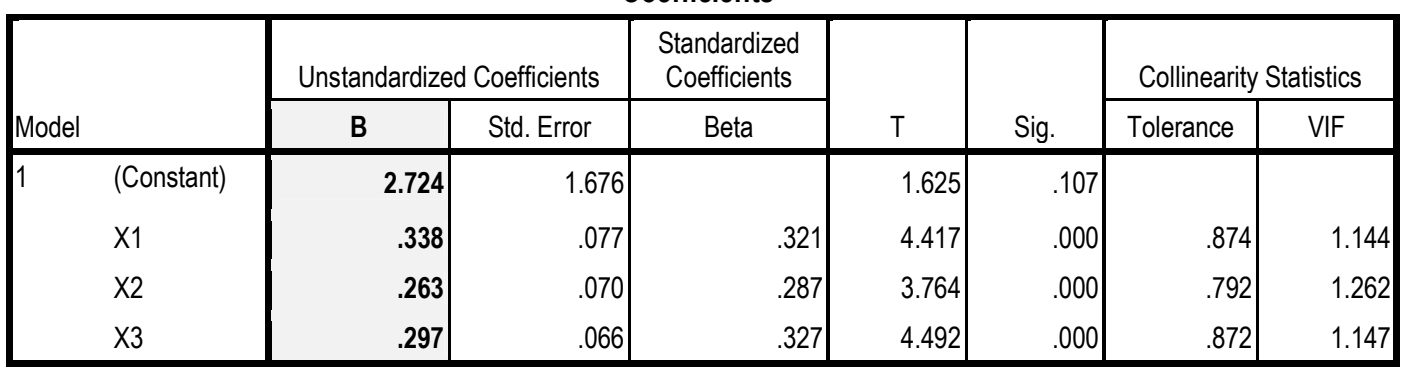




\begin{tabular}{|c|c|c|c|c|c|c|c|c|}
\hline \multicolumn{9}{|c|}{ Coefficients ${ }^{a}$} \\
\hline \multirow{2}{*}{\multicolumn{2}{|c|}{ Model }} & \multicolumn{2}{|c|}{ Unstandardized Coefficients } & $\begin{array}{l}\text { Standardized } \\
\text { Coefficients }\end{array}$ & \multirow[b]{2}{*}{$\mathrm{T}$} & \multirow[b]{2}{*}{ Sig. } & \multicolumn{2}{|c|}{ Collinearity Statistics } \\
\hline & & B & Std. Error & Beta & & & Tolerance & VIF \\
\hline \multirow[t]{4}{*}{1} & (Constant) & 2.724 & 1.676 & & 1.625 & .107 & & \\
\hline & $\mathrm{X} 1$ & .338 & .077 & .321 & 4.417 & .000 & .874 & 1.144 \\
\hline & $\mathrm{X} 2$ & .263 & .070 & .287 & 3.764 & .000 & .792 & 1.262 \\
\hline & $\mathrm{X} 3$ & .297 & .066 & .327 & 4.492 & .000 & .872 & 1.147 \\
\hline
\end{tabular}

a. Dependent Variable: $Y$

Keterangan:

- Nilai a untuk persamaan regresi $\mathrm{Y}=2,724$

- Nilai $b_{1}$ untuk persamaan regresi $Y=0,338$

- Nilai $\mathrm{b}_{2}$ untuk persamaan regresi $\mathrm{Y}=0,263$

- $\quad$ Nilai $b_{3}$ untuk persamaan regresi $Y=0,297$ berikut:

Dari nilai-nilai koefisien di atas dapat disusun persamaan regresi sebagai

$$
Y_{1 t}=2.742+0.338 X_{1}+0.263 X_{2}+0.297 X_{3}
$$

Persamaan di atas dapat disimpulkan sebagai berikut:

1. Apabila variabel lain bernilai konstan maka Nilai $Y$ akan berubah dengan sendirinya sebesar nilai konstanta yaitu 2,724.

2. Apabila variabel lain bernilai konstan maka Nilai Y akan berubah sebesar 0,338 setiap satu satuan $\mathrm{X}_{1}$.

3. Apabila variabel lain bernilai konstan maka Nilai Y akan berubah sebesar $\quad 0,263$ setiap satu satuan $\mathrm{X}_{2}$.

4. Apabila variabel lain bernilai konstan maka Nilai Y akan berubah sebesar 0,297 setiap satu satuan $\mathrm{X}_{3}$.

\section{Pembahasan:}

1. Pengetahuan zakat berpengaruh signifikan terhadap kesedian dosen UTP dalam membayar zakat profesi melalui pemotongan gaji.

2. Motivasi berpengaruh signifikan terhadap kesedian dosen UTP dalam membayar zakat profesi melalui pemotongan gaji.

3. Sosial Ekonomi berpengaruh signifikan terhadap kesedian dosen UTP dalam membayar zakat profesi melalui pemotongan gaji.

4. Pengetahuan zakat, motivasi membayar zakat dan sosial ekonomi berpengaruh signifikan terhadap kesedian dosen UTP dalam membayar zakat profesi melalui pemotongan gaji.

\section{Kaitan Zakat dengan Pengetahuan Zakat, Motivasi dan Sosial Ekonominya}

Zakat mempunyai potensi yang besar dalam mengentaskan kemiskinan. Namun, karena zakat merupakan ibadah mahdhah maka ia harus memenuhi dua syaratagar ia diterima oleh Allah SWT, yaitu ittiba' Lir Rasul (mengikuti cara atau petunjuk Rasul), kemudian ikhlas. Sebuah ibadah tidak cukup hanya ikhlas saja, atau beralasan kemashlahatan saja, namun harus mengikuti petunjuk dari Nabi Muhammad SAW. sehingga dalam menetapkan hukum dan tata cara zakat 
penghasilan profesi harus berdasarkan nas dan kaidah-kaidah syari'ah, bukan hanya berdasarkan asumsi-asumsi asas manfaat saja. (Sulaiman, 2016:25)

Pembayaran zakat bulanan setiap kali penerimaan merupakan keringanan yang diberikan kepada muzzaki dengan beberapa alasan yaitu:

a. Pembayaran zakat bulanan/ setiap perolehan yang diterima tidak terasa berat karena jumlah yang dikeluarkan kecil bila dibandingkan dengan pengeluaran sekaligus di akhir tahun.

b. Muzzaki atau orang yang mengeluarkan zakat setiap kali penerimaan tidak akan kesulitan dalam menetapkan masa jatuh tempo setiap penerimaan yang diterima, karena bisa saja jatuh temponya terjadi berkali-kali sesuai dengan kekayaan yang diterimanya pada waktu yang berbeda-beda.

c. Pengeluaran zakat bulanan akan memudahkan pengelolaan dan mempercepat pendistribusian kepada yang berhak menerimanya.

Bila seluruh rakyat sudah memahami zakat sebagai suatu kewajiban, serta menyadari arti pentingnya zakat dalam berbagai aspek kehidupan, maka dalam waktu dekat, pemulihan ekonomi nasional dalam waktu dekat akan mencapai kemakmuran sebagaimana yang terjadi pada masa khalifah Umar bin Abd Al-Aziz, dimana dana Negara saat itu surplus dan rakyat hidup dalam kemakmuran. (Mujahidin, 2017:84)

\section{Kesimpulan}

a. Pengetahuan zakat, motivasi membayar zakat dan sosial ekonomi berpengaruh positif dan signifikan terhadap kesediaan dosen UTP dalam membayar zakat profesi melalui pemotongan gaji.

b. Pengetahuan zakat berpengaruh positif dan signifikan terhadap kesediaan dosen UTP dalam membayar zakat profesi melalui pemotongan gaji.

c. Motivasi berpengaruh positif dan signifikan terhadap kesediaan dosen UTP dalam membayar zakat profesi melalui pemotongan gaji.

d. Sosial ekonomi berpengaruh positif dan signifikan terhadap kesediaan dosen UTP dalam membayar zakat profesi melalui pemotongan gaji.

\section{Saran}

a. Persoalan zakat adalah rendahnya tingkat pengetahuan umat Islam tentang zakat. Banyak yang beranggapan bahwa pengetahuan zakat hanyalah dibebankan terhadap orang-orang tertentu saja. Peranan Pemerintah terhadap persoalan zakat serta terus membenahi Lembaga- lembaga konsultasi zakat. Lembaga amil zakat hendaklah meningkatkan visi dan misinya hingga mampu menjangkau semua bidang profesi sehingga dapat dikembangkan sesuai dengan kebutuhan yang ada.

b. Hendaknya lembaga amil zakat resmi yang ada di kota Palembang dapat mensosialisasikan peranan zakat profesi ke Universitas Tridinanti Palembang dan universitas lainnya.

\section{Ucapan Terima Kasih}

Terima Kasih tim peneliti ucapkan kepada Yayasan Pendidikan Nasional Tridinanti (YPNT) Universitas Tridinanti Palembang yang telah memberikan dukungan moril dan bantuan Dana Penelitian Tahun Anggaran 2017/2018 kepada tim peneliti. 


\section{Referensi}

Absidah, Watini Dwi. (2011). Faktor-faktor yang Mempengaruhi Kesadaran Karyawan BRI Syariah Cabang Yogyakarta dalam Membayar Zakat Profesi. Skripsi. FMUINSK-BM-05-03/RO. UIN Sunan Kalijaga. Yogyakarta.

Badan Amil Zakat Nasional. Statistik Zakat Nasional. (2017). https://pid.baznas.go.id/wp-content/uploads/2018/08/Statistik-ZakatNasional-2017.pdf.

Dakhoir, Ahmad. (2015). Hukum Zakat. Aswaja Pressindo. Surabaya.

Departemen Agama Republik Indonesia. (2005). Al-Qur'an dan Terjemahannya. CV Penerbit Diponegoro. Bandung.

Dianingtyas, Anindita. (2011). Faktor-faktor yang Mempengaruhi Kesediaan Karyawan Membayar Zakat Profesi melalui Pemotongan Gaji (studi kasus Direktorat Jenderal Pebendaharaan Negara Departemen Keuangan RI). Media Ekonomi. Vol. 19, No. 3. Desember 2011.

Heri. (2018). Akuntansi Syariah. Grasindo. Jakarta.

Jackson. (2011). Pengelolaan Sumber Daya Manusia: Managing Human Resources. Penerbit Salemba Empat. Jakarta.

Koesomowidjojo dan Suci, RM. (2017). Analisis Beban Kerja. Penerbit Raih Asa Sukses. Jakarta.

Ladewi, dkk. (2014). Akuntansi Islam. Lembaga Penerbit Fakultas Ekonomi. Universitas Muhammadiyah Palembang (UMP).

Lembaga Penjamin Mutu (LPM). (2018) Data Dosen Universitas Tridinanti Palembang (UTP).

Mujahidin, Akhmad. (2017). Ekonomi Islam Sejarah, Konsep, Instrumen, Negara, dan Pasar. Raja Grafindo Persada. Depok.

Noe, Raymond A. (2011). Manajemen Sumber Daya Manusia Mencapai Keunggulan Bersaing. Penerbit Salemba Empat. Jakarta.

Peraturan Pemerintah Republik Indonesia Nomor 41. (2009). Tentang Tunjangan Profesi Guru dan Dosen, Tunjangan Khusus Guru dan Dosen, serta Tunjangan Kehormatan Profesor.

Peraturan Pemeritah Republik Indonesia Nomor 37. (2009). Tentang Dosen.

Sekaran, Uma. (2011). Research Methods for Business: Metode Penelitian untuk Bisnis. Penebit Salemba Empat. Jakarta. 
Shobirin. (2015). Teknik Pengelolaan Zakat Profesi. Jurnal Zakat dan Wakaf. Vol. 2 No. 2 Desember 2015. Alfabeta. Bandung.

Sugiyono. (2010). Metode Penelitian Kuantitatif dan Kualitatif. Penerbit Alfabeta. Bandung.

Sulaiman, Sofyan. (2016). Legalitas Syar'i Zakat Profesi. Jurnal Syari'ah. Vol. V. No. 1. April 2016.

Trihendradi, C. (2013). Langkah Mudah Menguasai SPSS 21. Penerbit Andi. Yogyakarta.

Wasilah dan Nurhayati. (2015). Akuntansi Syariah di Indonesia. Penerbit Salemba Empat. Jakarta. 